\title{
Nonverbal means for creating suspense in Bernard Werber's novellas
}

\author{
Zh. Buts, I. Kryvenets* \\ National Technical University of Ukraine "Igor Sikorsky Kyiv Polytechnic Institute”, Kyiv, Ukraine \\ *Corresponding author. E-mail: Irene_85@bigmir.net
}

Paper received 17.12.18; Accepted for publication 05.01.19.

\section{https://doi.org/10.31174/SEND-Ph2019-189VII55-01}

\begin{abstract}
The article focuses on nonverbal means of communication which serve for creating and conveying B. Werber's characters' emotional state of suspense to a reader. The interrelation of linguistic and extralinguistic text elements is defined. A role of kinetic, prosodic, extralinguistic, haptic, proxemic means in the plane of the text is outlined in the article. The above mentioned nonverbal means in the realm of the French writer's creative work enhance the author's intention to immerse the reader into the atmosphere of dangerous adventures. All of them play a significant part in creating of emotivity of conceptual domain in novellas under research from the collection «L'arbre des possibles et autres histoires».
\end{abstract}

Keywords: verbal means, nonverbal means, communication, emotivity, kinetics, prosody, extralinguistics, haptics, proxemics, conceptual domain.

Introduction. Linguistic study of emotions belongs to one of the directions of cognitive linguistics, research paradigm of which is focused on the analysis of human mind, mentality etc. Cognitive aspect of various text styles and literary genres study can be found in the works of Ukrainian scientists such as N.D. Arutyunova, L.I. Belekhova, O.P. Vorobyova, S. A. Zhabotynska and others. Among foreign linguists whose works deal with cognitive linguistics and semantics are N.N. Boldyriova, Y.S. Kubryakova, D. Geeraerts, E.H. Rosch, R. Langacker and others.

Literature review. The expression of emotions in an artwork text realm forms its emotivity, which in I.V. Mihovich's opinion is "semantic property inherent in the language which through the system of language means expresses the emotions as a fact of the psyche; social and individual emotions reflected in semantics of language units" [7, p. 88]. Among the French researchers a valid contribution to the study of nonverbal means, in particular their functions and significance, was made by G. Barrier. Ways to express emotions through nonverbal and paraverbal component of communication in the comic discourse were described by French linguist J.-Ch. Chabanne [9] in his work "Verbal, paraverbal et non-verbal dans l'interaction verbale humoristique". Russian scientists I.G. Rogova and Y.V. Kuzina explored the linguistic means for creating an atmosphere of suspense in the works of the thriller genre, [3]. The role of paraverbal and non-verbal means in fiction is studied by the Ukrainian researcher G.O. Leimonchenko [6], and ways of implication of plot suspense in Guillaume Musso's [2] fiction realm is V. I. Gordienko's subject of research.

Aims and tasks. Home and global trends to the study of language and nonverbal means of emotivity implementation in the fiction texts of various genres, as well as the lack of linguistic papers devoted to the works of French writer B. Werber determine the importance of the study. The purpose of our article is to specify nonverbal means for creating suspense in the genre of science fiction. The object of our study is the nonverbal means that are used to convey the character's feeling of suspense. The material of the study is five short stories included in Bernard Werber's collection "L'arbre des possibles et autres histoires".

Results and Dicussion. Using a dictionary entry, emotional stress is understood as "a state of inner concentration, mobilization before a possible unexpected situation, danger, etc." [10]. In our work we specifically consider the nonverbal means for creating and transmitting characters' emotional state of suspense to a reader.

The text is a medium of communication, where the leading role belongs to the verbal (linguistic) components of intercourse. However, F.S. Batsevych emphasizes on the importance of non-verbal means (hereinafter - NM) and understands them as "elements of a communicative code that have nonverbal (but iconic) nature along with the resources of the language code serves for the creation, rendering and perception of messages" [1, p. 59]. On the basis of studies carried out by scientists, the linguist confirms that the major part of communication is done without means of the language code, but with a focus on other nonverbal elements [ibid]. The scientist also highlights certain characteristics of nonverbal messages, considering them to be "unstructured (they cannot be decomposed into separate components), attached to the conditions of communication, spontaneous, etc." [ibid]. There is a peculiar division of functions between verbal and NM of communication. According to S.V. Shevchuk and I.V. Klimenko, pure information is transferred by verbal means, while the nonverbal means transfer the attitude to the interlocutor [8, p. 159]. Interaction between verbal and nonverbal components of communication is also studied by Russian psychologists V. Kunitsyna, N. Kazarinova and V. Pogolsha who single out functions of nonverbal means toward verbal ones:

- addition (duplication, amplification) of verbal messages;

- objections of verbal messages;

- substitution of verbal messages;

- regulation of the conversation [1, p. 61].

Learning sign language is the subject matter of paralinguistics. According to G.O. Leimonchenko one should distinguish between nonverbal and paraverbal means of communication. The researcher classifies those which "are made up of voices and intonation based on tonal and timbral features of language" as paraverbal ones [6]. But A.K. Kulichenko, studying the history of the issue of nonverbal communicative behavior and its components, notes that the interpretation of nonverbal communication is possible in either narrow or broad sense. In contrast to the wide sense, the narrow one does not include paralinguistic or voice components [4, p. 80]. In her works, the researcher refers paraverbal means to nonverbal ones and offers such components of nonverbal communicative human behavior:

- kinetics (posture, gesture, facial expression, walk);

- haptics (kissing, shaking hands, etc.); 
- paralinguistics (voice volume, speed and rhythm of speech, timbre, sonority, etc.);

- extralinguistics (pauses, groans, a laughter, crying, sighs, coughs);

- oculesics (gaze, direction and duration of gaze, eye movement, pupil size etc.);

- olfactics (body smell, the odor of cosmetics);

- gastics (food, drinks);

- proxemics (a distance, an orientation, an angle of communication, a location of personal belongings, a territoriality, etc.) [ibid].

Many scientists (S.V. Shevchuk, I.V. Klimenko, A.Th. Lesko, N.D. Pryschak, G.G. Ruzakova, O.B. Zaliubivska) refer paraverbal means of communication to nonverbal and determine them as prosodic and extralinguistic ones. In our study we support this opinion and subdivide all of NM into kinetic, prosodic, extralinguistic, haptic and proxemic.

The main feature of science fiction literary genre is scientifically well-founded assumptions, ideas and projects, which are fulfilled by the fictional characters. Each bold scientific idea that is implemented on the pages of science fiction works is accompanied by a number of emotional states, which are experienced by the characters: fear, joy, doubt etc. In texts of the genre under study the characters are often faced with events of so-called high risk: testing of new time and space travel technologies especially on long distances (for example, other solar systems, galaxies) and others. Undoubtedly, such travelling or research is accompanied by increasing suspense of the characters, which in fictional works can be expressed with the help of verbal and nonverbal means.

In 2002 Bernard Werber published a collection of short works-hypotheses called "L'arbre des possibles et autres histoires", where the author models fantastic situations, makes assumptions on various scientific and social themes. For example, in the novella "Le chant du papillon" he describes the expedition of the four-scientist crew to the Sun, where they discovered extraterrestrial inhabitants of a burning star. In compositional elements of the novella a characters' state of emotional suspense is different. In the exposition, where according to the plot the protagonist of the fictional work, Simon Katz talks to NASA about the very idea of traveling to the Sun, the suspense is felt for the first time. The novella starts with exclamatory sentence, which expresses the raise of NASA's Secretary's voice volume and tone of voice (prosodic means of communication): C'est strictement impossible! (This is absolutely impossible), and then adds: On ne peut pas lancer une expédition vers le Soleil, affirma le secrétaire général de la NASA en éclatant de rire (1, p.101). Used in the example NM of communication are those which most clearly convey to the reader the tense atmosphere that prevailed at the meeting. After all things that have been told NASA's Secretary exploded with laughter (en éclatant de rire) because of Simon Katz's bold idea. This extralinguistic medium, expressed by the phraseological unit éclater de rire, emphasizes the attitude of the speaker to things that are happening, his viewpoint, and having regard to the given situation - the ridicule and contempt to his interlocutor.

One of the most expressive techniques of suspense transferring is the use of kinetic means of communication: Le secrétaire tapa du platde la main sur la grande table d'acajou de la salle de réunion (1, p. 103). Being angry with Simon
Katz's insistence, NASA's Secretary slaps his palm on the table (tapa du plat de la main sur la grande table). This gesture embodies the emotion of anger that immediately creates the effect of acute, even conflict situation. In the text of the novella "Le chant du papillon" one can find extralinguistic means, which include pause, sigh, laugh, cry, etc. All of them are used to transfer emotivity in the text: De quoi griller vite fait une pintade, soupira Pamela, soudain pessimiste malgré son teint hâlé (1, p. 106). We also consider this example to be interesting because of the joke which is used by the author on the verbal level: De quoi griller vite fait une pintade (Have you got something to fry a chicken on). However, this expression is followed by a nonverbal element that denotes sigh (soupira) and creates a kind of contrast between spoken and experienced things. This fact confirms the importance of interpretation of verbal and nonverbal means of communication not in isolation but as a coherent whole.

In the novella «La dernière révolte», which is also included in the collection "L'arbre des possibles et autres histoires", the writer brings up an urgent social issue - a life of people over 60 is deprived of rights and freedoms. On the pages of his work, the author describes the horrible socio-political system in which the government does not want to spend money on the maintenance of elderly people, imprisons and murders them. Starting with the exposition, one can feel the terror of a frightened elderly couple, who is to be taken away by representatives of special services: Fred et Lucette se serrèrent l'un contre l'autre. Fred frémissait de colère: leur proper progéniture les avait donc abandonnés (1, p. 161).

To express characters' state of anxiety and despair B. Werber resorts to the nonverbal means, which stands for hugs (se serrèrent - pressed to each other) and in this context transmits the very emotion of fear and tension. Hugging belongs to haptic NM, because haptics is associated with tactile perception system and includes varieties of touch. Trembling of the main character (frémissait) (kinetic NM) is a display of his fear and emotional tension, which is certainly transmitted to the reader. The author more than once supplies the characters' dialogical speech of the novella "La dernière révolte" with haptic NM that implies trembling: N'ouvrons pas, ils croiront que nous sommes absents, murmura Fred, qui ne maîtrisait plus ses tremblements (1, p. 164). Besides trembling character's feeling of suspense is rendered by prosodic NM, expressed by the lexeme murmurer, v. (to whisper), because a reduction in the volume of the voice, as well as its increase is the characteristic feature of human behavior under stress, fear, suspense and so on.

Using the scientific research of V.A. Labunskaya, who has developed a scheme of facial codes of human emotional states [5], we also refer peculiarities of gait and movement to NM. In the philosophical novella "Le règnedesapparences", which belongs to the genre of humanitarian (soft) science fiction, B. Werber makes the situation of the disappearance of the material covering of things and later people possible. Instead of them a short text message that briefly describes the object or person appears. The protagonist of the fictional work, a professor of philosophy, Gabriel Nemrod, is shocked by the fact that things are disappearing around him and instead the words appear. The man could not believe his eyes and through the whole text is in a state of stress and panic. To express his suspense the author describes the character's actions and movements, which in our study are defined as proxemic NM: Ils'avança, passaunemainautravers. Quand il recula, il y eut 
de nouveau comme du flou et lemur reprit sa place (1, p.25). In this example, the character's state of emotional suspense borders with his curiosity. A wall vanished in the air right in front of him and a short text was formed instead. Impressed by what he saw Gabriele Nemrod first decided to approach ( $s^{\prime}$ avança), then to touch (passaunemainautravers), and after making sure that everything really happened, he retreated (recula). We believe that such detailed description of actions implemented in the text with the help of the NM, the latter are arranged in such a way to increase suspense (approach $\rightarrow$ touch $\rightarrow$ retreat), is a medium of creating emotional conceptual domain of the work as a whole, in particular by introducing the character's state of inner anxiety and fear in the literary text.

The adventure novel "Vacances à Montfaucon" runs about Pierre Luberon's, the main character, who made a journey into the XVIIth century. His adventures end with his imprisonment on charges of witchcraft. With this plot twist the character's emotional state of tension, which is caused by not knowing how to avoid punishment and return to his life, is conveyed to a reader especially thrillingly. To describe Pierre Luberon's emotional experience and fear, the author uses kinetic NM, namely expressive movements, which include facial expressions: Pierre se mord les lèvres, au comble de l'angoisse (1, p. $55)$. In the text of the novel one can come across prosodic NM like a sigh: Il sont sans doute l'intention de nous torturer jusqu'à nous faire avouer notre pacte avec Satan, soupire le possesseur de l'appareil photo (1, p. 55) and tone of voice: C'est en effet une très bonne idée, reconnaît Pierre Luberon, balbutiant (1, p. 57). Sigh (soupire) and mumbling (balbutiant) convey the melancholy of the main character, who has already no hope for salvation. The state of doom is vividly depicted in such kinetic means of non-verbal communication as closing your eyes: Il ferme les yeux et revoit en un instant les meilleurs moments de son existence (1, p.56). Before the execution Pierre Luberon decided to recall the best moments of his life, and to focus on it he closed his eyes. However, in our opinion, such actions embody a non-peaceful state of the main character, but rather an attempt to overcome the excessive suspense that he felt.
The collection «L'arbre des possibles et autres histoires» includes the stories of the fantasy genre, but each of them has its own stylistic narrative features. The novella «L'amisilencieux» has elements of both detective and science-fiction genres. The narrator of the novella is a tree that describes the events that occurred with three friends: Anaïs, Charlotte and Marie-Natasha. Girls rob jewelry stores and hide diamonds at the foot of a tree, which is the best friend of one of them. The name of the tree is Georges, it thinks and goes through all typical human emotions and it is even in love with his friend Anaiis. Relationship between accomplices is rather strained as they don't trust each other. Such relations are expressed in the text with the help of NM: Silence. Les prunelles se défiaient. Chacunescruta les deux autres (1, p. 230). On the basis of F.S. Batsevych's classification, a pause (silence) is referred to extralinguistic means of non-verbal communication and girls' gazes (Les prunelles se défiaient. Chacunescruta les deux autres) are defined as kinetic. One day the heroines of novella fight and murders occur in front of Georges: two of three girls, including Anaïs, die. George is in despair. He tries to help the investigation and to point out the killer, but has no such possibility.

Conclusion. To sum up, the analysis of the NM of creating and conveying the emotional state of the characters' suspense in novellas under study helped to distinguish and find in the texts NM such as kinetic, prosodic, extralinguistic, haptic and proxemic. Among these types of NM, a leading role is played by kinetic components of non-verbal communication which are presented by movements, gestures, posture, facial expressions and so on. In our study, the emotional state of stress correlates to such concepts as fear, despair, insecurity, panic and so on. We assume that in the textual space of selected works of NM enables the intention of the author to immerse the reader into the atmosphere of dangerous adventures. The latter also play a major role in creating general conceptual space of dangerous adventures not of each story separately but of the entire collection «L'arbre des possibles et autres histoires».

We consider the analysis of the role of nonverbal means in establishing emotional conceptual space in Bernard Werber's creative plane to be perspective for our further study.

\section{REFERENCES}

1. Batsevych, F.S. (2004) Osnovy Comunicatyvnoii Lingvistyky [The Basis of Communicative Linguistics]. Kyiv: Alma-mater.

2. Gordienko, O.I. (2013) Sposoby stvorennia efectu saspensu v suchasnomu sentymentalno-prygodnytskomu romani (na materiali tvoriv G. Miusso) [The ways of Creation Suspense in Modern Sentimental and Anventure Novel (based on works of G. Musso)]. Problemy semantyky slova, rechennia ta tekstu. Is. 31, pp. 70-76. http://nbuv.gov.ua/UJRN/pssrtt_2013_31_11

3. Zhogova I.G., Kuzina Ye.V. Iazykovyie sredstva sozdaniia atmosfery napriazhennosti [The Linguistic Means of Creating Suspense in a Thriller Novel (with regards to novels by g. Grisham and $m$. Stewart)]. http://cyberleninka.ru/article/n/

4. Kulichenko A.K. (2011) Neverbalna komunikatyvna povedinka ta ii komponenty z istorii pytannia [Nonverbal Communicative Behaviour and its Components in the History of the Issue] Is.1, pp. 78-84.

5. Labunskaya V.A. (1986) Neverbalnoie povedeniie (sotsialnopertseptivnyi podhod) [Nonverbal Behaviour (Social and Perceptive Approach)]. Rostov: Izdatelsvo Rostovskogo Universiteta. Pp. 5-35. http://psylist.net/hrestomati/00008.htm

6. Leimonchenko G. (2011) Paraverbalni i neverbalni osoblyvosti komunicatsii, predstavleni v hudozhniomu teksti [Paraverbal and Nonverbal Peculiarities of Communication, which are Represented in the Fiction Text]. Lingvistychni Studii. Is. 23, pp. 166170. http://nbuv.gov.ua/UJRN/lingst_2011_23_39

7. Migovich, I.V. (2010) Do pytannia pro funktsionuvannia kategorii emotyvnosti u kognityvnii paradygmy movoznavstva [To the question of functioning the emotive category within cognitive paradigm of linguistics]. Visnyk LNU imeni Tarasa Shevchenka. Is.20, pp. $87-91$.

8. Shevchuk S.V., Klymenko I.V. (2012) Ukraiinska mova za profesiinym spriamuvanniam. Pidruchnyk [Profession-oriented Ukrainian language studies. Manual]. Kyiv: Alerta.

9. Chabanne J.C. (1995) «Verbal, paraverbal et non-verbal dans l'interaction humoristique », dans Approches du discours comique, actes de la journée d'étude Adiscom-Corhum (juillet 1995), dir. J.M. Dufays et L. Rosier. Bruxelles : Mardaga, , coll. «Philosophie et langage ». P. 35-53

10. Worldwide dictionary of the Ukrainian Language. Retrieved from http://uk.worldwidedictionary.org/

REFERENCES OF ILLUSTRATIVE MATERIAL:

1. L'Arbre des possibles et autres histoires (2002), Bernard Werber, éd. Le Livre de Poche (Origine : Albin Michel), 2004. - 288 p. 